scien do Zagreb International Review of Economics \& Business, Vol. 22, Special Conference Issue, pp. 37-67, 2019

(C) 2019 Faculty of Economics and Business, University of Zagreb and De Gruyter Open All rights reserved. Printed in Croatia

ISSN 1331-5609; UDC: $33+65$

DOI: 10.2478 /zireb-2019-0004

CONFERENCE PAPER

\title{
Effects of the Establishment of Entrepreneurial Orientation on the Performances of Small and Medium Enterprises in Transition Countries: Empirical Evidences from Bosnia and Herzegovina
}

\author{
Saša Petković" \\ Snežana Sorak ${ }^{* *}$
}

\begin{abstract}
Bosnia and Herzegovina (BiH) has a relatively low level of entrepreneurial activity as evidenced by GEM reports but also has an economic structure in which SMEs account for about $99 \%$ of the total number of enterprises. The goal of this paper was to examine the level of entrepreneurial orientation (EO) and influence of EO on business performances of SMEs in the Republic of Srpska (RS), one of the two BiH entities, in which the empirical research was done. We have used adapted Covin \& Slevin (1989) version of the questionnaire. We found out that only $12.28 \%$ of sampled SMEs have all three dimensions of EO pronounced. The least pronounced dimension is risk-taking and the most pronounced dimension is proactiveness. Our research did not confirm the impact of EO on selected indicators of business performances.
\end{abstract}

Keywords: Small and medium enterprises; transition; strategies; entrepreneurial orientation; performances

JEL Classification: L25, L26

\section{Introduction}

Entrepreneurial orientation (EO) has become one of the most established constructs in entrepreneurship and broader management research, and a number of reviews of the EO literature in last couple of decades including recent one have been conducted

\footnotetext{
* Saša Petković is at University of Banja Luka, Faculty of Economics, Banja Luka, Bosnia and Herzegovina.

${ }^{* *}$ Snežana Sorak is at Tax Administration of Republic of Srpska, Banja Luka, Bosnia and Herzegovina.
} 
(Covin \& Lumpkin, 2011; Covin \& Wales, 2012; Covin \& Miller, 2014; Anderson, Kreiser, Kuratko, Hornsby, \& Eshima, 2015; Wales, 2016). The processes of strategy-making and the styles of firms engaging in entrepreneurial activities are together referred to as "entrepreneurship orientation", as argue Lumpkin and Dess (2001). Miller (1983, p. 771), as state Rezaei, Ortt and Scholten (2013, p. 2750), defines an entrepreneurial firm as "one that engages in product market innovation, undertakes somewhat risky ventures, and is first to come up with 'proactive' innovations, beating competitors to the punch. This definition contains the three dimensions of EO: innovativeness, risk-taking and proactiveness". In the literature, there was a lot of discussion related to whether EO should be seen as multi-dimensional, or whether its dimensions differently affect the performance of the organization. A large number of authors combines three dimensions in one and observe $\mathrm{EO}$ as an one-dimensional concept (Covin \& Slevin, 1989; Naman \& Slevin, 1993; Wiklund \& Shepherd, 2003), while some theories suggest that the dimensions of EO affect in different ways the performance of enterprises (Lumpkin \& Dess, 2001; Covin, Green, \& Slevin, 2006). Business success of small and medium enterprises (SMEs) in small transitional economies such as Bosnia and Herzegovina $(\mathrm{BiH})$, can be viewed from the angle of impact of external factors of institutional support to development of entrepreneurship through the development and operations of institutions of entrepreneurial infrastructure (such as, for example, angel investors market, venture capital funds, clusters, incubators, accelerators, development agencies, guarantee funds, and other key institutions), as well as from the point of possible application of $\mathrm{EO}$ as one of the potential internal factors of business success of SMEs. Measuring EO is important for entrepreneurial firms and for organizations like venture capitalists, business angels, investment banks and governments investing in these firms (Rezaei et al., 2013). The purpose of this study was to examine the influence of the EO of SMEs on their performances in the Republic of Srpska (RS), one of the two BiH entities in which the empirical research was done. Firms need to know their entrepreneurial level if they are to invest in entrepreneurial activities and improve their performance (Rezaei et al., 2013). For this purpose, in 2016 we conducted quantitative research on a sample of 57 respondents, in order to obtain answers to the following question: Are SMEs applying entrepreneurial orientation and how it affects their performances? We have used adapted Covin and Slevin (1989) version of the questionnaire which examines characteristics of companies with following three constructs of the EO: innovativeness, proactiveness and risk-taking. The paper is divided into four major sections. Drawing on prior research and theory in Literature review, the next section advances hypotheses suggesting three EO dimensions and performance relationships. Then, the field research methodology, instrumentation and analysis are discussed. The final two sections, discussion and conclusion present the findings and discuss the practical and theoretical implications of the research. 


\section{Literature Review}

As Ramadani and Dana (2013, p. 218) state: “Transitional economies provide a particularly fascinating backdrop for the development of entrepreneurship”. Trivić and Petković (2015) emphasize the importance of quality institutions and institutional environment for the implementation of the transition process, implying as institutions the Douglass North's concept, according to which institutions represent rules and regulations that make political, economic and social interactions, and consist of formal rules (constitution, laws, property rights) and informal constraints (sanctions, taboos, customs, traditions and rules of conduct). The transition process in $\mathrm{BiH}$ is not yet completed. At the heart of the transition process is institution building, as well as the development of entrepreneurship and SMEs (Hisrich, Petković, Ramadani, \& Dana, 2016). Many studies have shown that developed countries that have encouraged entrepreneurship and development of SME sector, had higher economic growth (Audretsch \& Thurik, 2000; Ács \& Naudé, 2013; Naudé, 2013). Entrepreneurship is also associated with the development of developing countries, considering entrepreneurial activity as an important driver of economic growth in these countries (Audretsch, Ketlbach, \& Lehmann, 2006; Van Praag \& Versloot, 2007). The report of the European Commission on the progress of $\mathrm{BiH}$ (2013) states that $\mathrm{BiH}$ has not made significant progress in the implementation of the Small Business Act (2008). Slow implementation of contracts, limited access to financing and political instability represent the most problematic factors for doing business in $\mathrm{BiH}$. It was concluded that the regulatory environment remained complex, that the regulatory burden on SMEs was heavy, and that no significant progress was made in the field of industrial as well as SMEs development policies. Operational policies are fragmented and not coordinated, and the choice and quality of support services to SMEs are limited (European Commission, 2013). According to the World Bank's report Doing Business, out of 189 countries $\mathrm{BiH}$ is ranked at $79^{\text {th }}$ place when it comes to ease of doing business for SMEs, while in 2017 it fell in the rankings by two places (The World Bank, 2017). All other countries in the region are better ranked than $\mathrm{BiH}$, with the exception of Albania, which is on the $97^{\text {th }}$ place. The report covers areas which are of great influence on the possibility of initiating, developing and closing businesses, such as: starting a business, obtaining construction permits and approvals, access to finance, protecting the rights of investors, paying taxes, trading with foreign countries and others. SMEs in $\mathrm{BiH}$, as we have elaborated, operate in a relatively unfavorable environment. Does it work for SMEs in $\mathrm{BiH}$ to apply $\mathrm{EO}$ with three main dimensions, namely: innovativeness, risk-taking and proactiveness? Claims of Lumpkin and Dess (2001) on the multidimensionality of EO are confirmed by Hughes and Morgan (2007). Namely, they examined the influence of EO dimensions on the performance in the case of high technology companies in the embryonic stage of development. They found that 
proactiveness and innovativeness have a positive influence on business performance, while risk-taking has a negative influence, and that competitive aggressiveness and autonomy have no effect on the performance at this stage of the company's growth. Soininen (2013) believes that EO may have an influence on a different ability of a company to withstand difficulties in business operations. The research results of Soininen (2013) have shown that in the first phase of the economic crisis, risk-taking has a negative influence on profitability and liquidity, while innovativeness and proactiveness can mitigate its negative influence on liquidity. Does the application of $\mathrm{EO}$ in SMEs can change this bleak picture of the state of the economy in $\mathrm{BiH}$ ? Do entrepreneurially oriented SMEs in small transition countries such as $\mathrm{BiH}$ achieve better performance than companies that do not apply all three dominant dimensions of the EO? These two issues are dominant in this empirical research.

\section{Theoretical Background, Model and Hypotheses}

Entrepreneurial culture has a positive influence on innovations as well as on creation of value for a customer, allowing members of the organization to be more willing to take risks and to be more proactive when delivering value for customers according to their needs (Nasution, Mavondo, Matanda, \& Ndubisi, 2011). EO, as a central concept of management and as a key driver of economic activity, has become a central theme in the studies on entrepreneurship and has been accepted as a universally used measure of entrepreneurial activity (Edmond \& Wiklund, 2010; Yoo, 2015). Rauch, Wiklund, Frese and Lumpkin (2009) suggest that the concept of EO has been used in more than 100 studies, which indicates a wide acceptance of the conceptual meaning and relevance of this concept. Empirical researches on the influence of the application of the concept of EO on the performance of the company have special importance in academic circles. In this regard, today we talk about the traditional measuring of the company's performances, based on financial benchmarks, and the modern measuring of the company's performances, which, in addition to financial benchmarks, also takes into account other non-financial parameters that can respond to the needs and requirements of business enterprises in modern conditions (Ittner \& Larcker, 1998). Performance benchmarks for this should be designed in order to reflect those factors that have the greatest influence on the efficiency of important processes in the company. Defining such a system of performance measuring is not easy, because the answer to the question "What is optimal?" differs from one situation to another (Tangen, 2004).

While some studies have found that companies which apply strong EO operate much better than the ones which do not adopt it (Covin \& Slevin, 1986; Wiklund \& Shepherd, 2003), other studies have, however, established a lower degree of correlation between EO and performances (Dimitratos, Lioukas, \& Carter, 2004; Zahra, 
1991), while some authors have not found any connection with business profitability (Slater \& Narver, 2000; George, Wood, \& Khan, 2001). Magnitude of the relationship between EO and company's performances varies in different studies. Rauch et al. (2009) consider that analysis of the relationship between EO and company's performances should also include moderators, such as company's activity, company's size and cultural differences, because these factors can influence their relationship. A large number of oral and empirical evidences supporting a positive relationship between entrepreneurship and performances have led to the situation where many managers take a high level of entrepreneurial activity, although it may be to the detriment of the company, because EO does not always have to appropriate (Wiklund, 1999). For these reasons, caution is needed before suggesting companies to adopt EO.

From the above elaborated theoretical concept of EO, the basic hypothesis that we will try to prove by the empirical research reads as follows:

H0: Application of entrepreneurial orientation in the sector of small and medium enterprises in small transition countries will contribute to achieving better performances in these companies.

The First Construct of Entrepreneurial Orientation - Tendency to Risk-Taking

Risk-taking refers to the tendency of a company to take bold actions, such as entering new unknown markets, investing significant resources in activities with an uncertain outcome, as well as significant borrowings (Lumpkin \& Dess, 1996). The willingness to take risks actually shows how a company makes decisions in situations when it needs to invest significant resources in activities that have a high possibility of failure, but that can bring big profits. Companies that have a strong EO are ready to be exposed to higher borrowing or more significant investment of resources in an effort to seize market opportunities, with the aim of obtaining a high return on invested capital (Knight, 2000). Entrepreneurial firms are more prone to risk-taking in comparison with other companies, which, due to risk aversion avoid business activities with an uncertain outcome. Risk-taking is actually a tendency of companies to move from foreseeable situation, i.e. from safe and established paths to situations which are less known, but which give the possibility of exploiting opportunities with the investment of significant resources (Covin \& Slevin, 1991; Wiklund \& Shepherd, 2005). Vij and Bedi (2012) suggest that the ability of risk-taking of entrepreneurs is affected by factors, such as the result of risk-taking in the past and the ability to act in situations of risk. Studies have found a positive relationship between risk-taking and company's performances, i.e. that higher level of risk-taking also ensures better performances (Rauch, Wiklund, Freese, \& Lumpkin, 2004; Wang \& Yen, 2012 in Ambad \& Wahab, 2013). Lumpkin and Dess (1996) argue that future research will show that 
risk-taking and autonomy are necessary dimensions for all new ventures, and that innovativeness, proactiveness and competitive aggressiveness are present only under certain conditions. Therefore, the risk-taking is actually a dimension which is necessary as a support to both innovativeness and proactiveness. So, for the realization of innovation the company has to be ready to invest significant resources, although it may be that it cannot be successfully implemented (Patel \& D'Souza, 2009).

Based on the above elaborated, the first auxiliary hypothesis we define as follows:

H1: The tendency of managers of SMEs to actively take risks will contribute to a better business success of the company.

\section{The Second Construct of Entrepreneurial Orientation - Innovativeness}

Innovativeness represents a means by which companies are searching for new opportunities. Schumpeter (1934; 1942), as stated in Taylor (2013), was among the first who emphasized the role of innovations in the entrepreneurial process. The dimension of innovativeness refers to the willingness of a company to continuously introduce new methods and techniques in the work processes, to find new ways to perform the tasks, and to constantly develop new products, processes and services. Innovativeness also implies tendency of SMEs to creatively initiate and support new ideas, to experiment, create new processes which can result in new and/or better products, services or new markets (Kropp \& Zolin, 2005; Li, 2012 stated in Taylor, 2013). Methods for measuring the innovativeness in the company are different. One way is to examine the attitudes of managers to new ideas, and their willingness to abandon old beliefs and to work on finding new opportunities. Number of new products and services, as well as the frequency of their changes can also be an indicator of the measure of company's degree of innovativeness. Also, the resources that are invested in research and development can be used as a measure of the degree of innovativeness (Lumpkin \& Dess, 1996). From the above mentioned, the second auxiliary hypothesis reads as follows:

H2: Investments in research and development as well as technological and non-technological innovations, and implementation of new practices, will allow SMEs to increase sales growth.

The Third Construct of Entrepreneurial Orientation - Proactiveness

Proactiveness as a dimension of EO refers to the attitude that the company has in comparison with its competitors. A proactive company seeks to change the current situation and to be among the first to anticipate development trends, rather than to react to them subsequently. In this sense, Lieberman and Montgomery (1988) state that 
a proactive company will be able to take advantage that pioneers have, because in this way they will use market opportunities the best. They believe that proactiveness is the best strategy to compete with the competition. Lumpkin and Dess (1996) state that it will allow companies to earn huge profits, to establish a recognizable brand, but also to ensure customer loyalty. Lumpkin and Dess (2001) define proactiveness as seeking opportunities and as prospects facing the future. According to them (Lumpkin and Dess, 2001), proactiveness involves the introduction of new products and services before the competition, as well as the participation of a company in predicting and responding to the future needs and desires of the environment. Proactiveness can, therefore, manifest itself in two ways, as aggressive behavior in comparison with competing companies, or as seeking for favorable business opportunities. Proactiveness can simply be considered as the ability to take initiative, whenever the situation requires it. It allows companies to proactively search for information and resources in order to meet the projected demand (Vij \& Bedi, 2012). Proactiveness is the key to EO because it implies looking ahead. Proactive company tends to be focused on anticipating demand and future needs, which allows it to participate in changing environment and to influence the moves of competitors (Morgan \& Strong, 2003). These characteristics enable the company to achieve high performances, but it should be noted that according to Coulthard's (2007) study proactiveness will have a stronger influence on improving performances in the embryonic stage of development of the company, while the importance of this dimension is smaller in existing companies. Compared with innovativeness which is focused on the creation of new combinations of products, proactiveness is more focused on the initiatives undertaken by the company. Thus, proactiveness as a way of seeking opportunities for innovation may be regarded as complementary to the innovativeness (Patel \& D'Souza, 2009).

Based on the above elaborated, we will construct a third auxiliary hypothesis.

H3: Ability of the SMEs management or entrepreneur to act proactively will provide a better competitive position of the company.

The order of constructs of the entrepreneurial orientation, and thus the auxiliary hypotheses, is not written in the order of importance and strength of influence in the multidimensional approach, such as the approach of entrepreneurial orientation that we apply in this empirical research.

\section{Research Methods and Results}

The effects of the establishment of EO on the performances of SMEs are the subject of analysis in this research. Since this problem has not been sufficiently researched in $\mathrm{BiH}$ so far, in this research we have looked for the answer to the question of 
how much SMEs apply EO and how it affects their performances? We observed EO in this paper as a construct consisting of three dimensions: innovativeness, proactiveness and risk-taking, while the dimensions of autonomy and competitive aggressiveness were not studied. We focused the area of the research on the entity Republic of Srpska (RS) (49\% of $\mathrm{BiH})$. With a view to obtaining answers to the research questions, we conducted a quantitative research using the questionnaire in the online version.

\section{Plan and Research Methods}

The purpose of this research was to evaluate the interdependence between the established EO and its effects on the performances of SMEs in $\mathrm{BiH}$. In fact, previous researches on this topic have produced conflicting results, because some researches have shown that higher level of EO has a positive effect on performances (Zahra \& Covin, 1995; Wiklund, 1999; Soininen, 2013), while other authors did not find association between these two variables (Slater \& Narver, 2000; George et al., 2001). Are there in the transition country and the country with a complex constitutional structure such as $\mathrm{BiH}$ (the three constituent peoples, four levels of government - state, entity, cantonal and local level, plus one District) companies that are entrepreneurially oriented, and what are the effects of EO on the performances of these companies? In order to test the set hypotheses and find answers to the above-defined research question, we conducted an empirical research in the period from $29^{\text {th }}$ of November 2015 to $21^{\text {st }}$ of September 2016 using the random sample survey method and collected 62 questionnaires. The sample included companies with up to 250 employees, according to the classification of enterprises defined by the Law on SMEs Development (Official Gazette of the Republic of Srpska, 2013). Thus, according to the Law on SMEs Development (Official Gazette of the Republic of Srpska, no. 50/13) status of SMEs is given to companies, other legal entities and entrepreneurs who meet the following criteria:

a) they employ fewer than 250 employees annually in average,

b) they are independent in their business operations, and

c) they achieve annual turnover of less than $8,000,000$ BAM or have a value of business property up to 4,000,000 BAM.

The research was conducted on the territory of five cities and seven municipalities in $\mathrm{BiH}$, i.e. in the RS. The link containing the questionnaire was forwarded to about 2,000 e-mail addresses of owners or executive directors of selected companies. The sample was composed by using the data from Intermediary Agency for IT and financial services ad Banja Luka (APIF), wherein the company size based on the number of employees was taken as a criterion for the selection of companies in the sample. Therefore, the sample included only those companies whose number of employees 
did not exceed 250 and sample was consisted of 57 SMEs. We measured the attitudes of participants and examined the facts, using 24 questions. We have used adapted Covin and Slevin (1989) version of the questionnaire which examines characteristics of companies with following three constructs of the entrepreneurial orientation: innovativeness, proactiveness and risk-taking. In the test phase, we sent a questionnaire to 5 addresses (entrepreneurs, managers and owners of SMEs), to verify whether the questions were clearly formulated and we made corrections in questions 8 and 13 . The participants, who are owners or managers of the company, have independently filled in a questionnaire, which was created in a way that can be completed in a period between 10 and 15 minutes.

\section{Limitations in the Research}

We consider the lack of interest of a large number of owners and managers of SMEs to fill in a questionnaire as the major limitation in this research. In addition to the sample size limitations in the research also refer to participants in the study. This refers to the fact that this research was based on subjective perceptions of representatives of companies, in which the owners were generally managers, so there was a possibility that during the evaluation of their internal or external organizational environments they were biased. What could be added to the aforementioned was the insufficient knowledge of the matter by the persons who filled in a questionnaire. In addition, there is a possibility that the questionnaires, again due to lack of interest for the participation in the research, were not filled in by the owners or managers, but by some third persons in the company. In the statistical inference process, research results cannot be interpreted for the entire statistical weight, which is a basic lack of the research. In the next research, the observed deficiencies can be minimized through additional qualitative research.

\section{Research Results}

Data were collected using a link which stored the answers in a database within the Google Docs (Google Drive) segment in the Gmail user account. We "exported" the obtained data in Excel tables and conducted their analysis. Data were statistically analyzed in the statistical program SPSS, version 17. The questionnaire, which was used to collect data on attitudes and opinions of participants consisted of 24 questions, bearing in mind that questions 8 and 13 consisted of a number of statements that were evaluated with a scale from to 1 to 5 . We will present the obtained results of the research below in graphic and tabular presentations. 


\section{Basic Data about the Participants}

In the first part of the questionnaire, we asked the participants to answer questions about the name, seat, year of establishment, organizational form and ownership structure of the company, company's activity and number of employees. The research was conducted on the territory of five cities and seven municipalities, which we presented in Table 1.

Table 1: Seat of the company

\begin{tabular}{|l|c|}
\hline \multicolumn{1}{|c|}{ Seat of the company } & Number of companies \\
\hline Banja Luka & 30 \\
\hline Laktaši & 5 \\
\hline Prijedor & 5 \\
\hline Čelinac & 3 \\
\hline Teslić & 3 \\
\hline Bijeljina & 2 \\
\hline Doboj & 2 \\
\hline Kozarska Dubica & 2 \\
\hline Srbac & 2 \\
\hline Gradiška & 1 \\
\hline Mrkonjić Grad & 1 \\
\hline Trebinje & 1 \\
\hline & 57 \\
\hline
\end{tabular}

Source: Authors

When it comes to the age of the company, the oldest company in the sample was established in 1950, while one company was established in 2013. The average age of the company is 19.72 years, i.e. the average company which participated in the sample was established in 1996. However, this data cannot be considered completely relevant, because the standard deviation is high at 11.54. This means that the age of the company, on average deviates from the average age of the company (19.72 years) by 11.54 years. Median, calculated on the basis of chronologically arranged data on the year of establishment of the company, was presented by the year 1999. This means that $50 \%$ of companies in the sample was established before 1999 , and $50 \%$ of companies was established after 1999. Most companies (6 or 10.53\%) in the sample were established in year 2000.

If the analyzed data on the activities of the sampled companies, i.e. activities on the basis of which these companies achieve most of their revenues are shown in a tabular view, we notice that most of the companies come from the processing industry. They are followed by companies from the following activities: information and communication, construction, wholesale and retail trade, professional, scientific and technical activities, agriculture, forestry and fishing, transportation and storage, while four activities were presented by only one company each (Table 2). 
Table 2: Basic activity of the company

\begin{tabular}{|l|c|c|}
\hline \multicolumn{1}{|c|}{ Description of the activity } & Number of companies & $\begin{array}{c}\text { \% of the total number of } \\
\text { companies }\end{array}$ \\
\hline Manufacturing & 21 & $36.84 \%$ \\
\hline Information and communication & 8 & $14.04 \%$ \\
\hline Construction & 7 & $12.28 \%$ \\
\hline Wholesale and retail trade & 7 & $12.28 \%$ \\
\hline Professional, scientific and technical activities & 3 & $7.02 \%$ \\
\hline Agriculture, forestry and fishing & 3 & $5.26 \%$ \\
\hline Transportation and storage & 1 & $5.26 \%$ \\
\hline Mining and quarrying & 1 & $1.75 \%$ \\
\hline $\begin{array}{l}\text { Production and supply of electricity, gas, steam } \\
\text { and air conditioning }\end{array}$ & 1 & $1.75 \%$ \\
\hline $\begin{array}{l}\text { Water supply; sewerage, waste management and } \\
\text { environmental remediation activities }\end{array}$ & 1 & $1.75 \%$ \\
\hline Administrative and support service activities & 57 & $1.75 \%$ \\
\hline TOTAL & $100 \%$ \\
\hline
\end{tabular}

Source: Authors

In terms of number of employees in the companies that participated in the sample, the highest percentage, i.e. $47.37 \%$ of participants belong to the category of small enterprises, $28.07 \%$ are micro enterprises while $24.56 \%$ of the sample relates to medium-sized enterprises.

\section{Entrepreneurial Orientation of the Companies and Its Determinants}

In the second part of the questionnaire, we have investigated to what extent SMEs are entrepreneurially oriented, and what are the characteristics of the organizational structure and the environment in which they operate. We have also examined the availability of resources and whether companies have educated owners or managers, as well as how much they are willing to complement the knowledge and skills needed to run their businesses. In order to determine the presence of entrepreneurial orientation in the organization, we requested from the participants to mark the three claims for each dimension of EO with marks 1-5, based on the attitude of the company's manager or owner towards the tendency to risk-taking, innovativeness and proactiveness. In order to consider that the company has a tendency to the particular dimension, we determined as a criterion that it should have at least two marks 4 or 5 , wherein the third mark cannot be smaller than 3. On the basis of this criterion, it was discovered that only 7 of 57 companies from the sample, i.e. $12.28 \%$ of the examined companies expressed all three dimensions of EO. Observed individually by dimen- 
sions of EO, it was found that 19 companies or $33.33 \%$ are oriented to risk-taking, 21 companies or $36.84 \%$ are oriented to innovativeness and 26 companies or $45.61 \%$ are oriented to proactiveness. We have also examined the dynamism and heterogeneity of the environment, as factors that may affect the $\mathrm{EO}$, on the basis of claims that were marked with marks 1-5.

Based on marks from the questionnaire, companies were divided into two groups (below and above the mean mark - median). It has been found that there are more of those companies which operate in a dynamic environment, $57.9 \%$, while $42.1 \%$ of companies marked their environment as less dynamic. On the other hand, when we consider the heterogeneity of the environment, $56.1 \%$ of companies believe that the environment in which they operate is not heterogeneous, while $43.9 \%$ of companies marked their environment as heterogeneous. In order to determine whether companies have managers with appropriate experience and knowledge necessary for running the business, we have asked a large number of questions, and the answers are presented below. In 27 of 57 sampled companies, i.e. $47.37 \%$ of companies, the owner or manager does not have a diploma of higher education institution in the field of economics or management (if they are not the same person none of them has a diploma), while 30 companies, or $52.63 \%$ have responded affirmatively to this question, which means that the owner or manager has a diploma of higher education institution in the field of economics or management (if the owner or manager are not the same person then one of them possesses a diploma, of which in 4 companies owner has a diploma and manager does not have it). To the question whether the owner/manager and their team possess adequate (sufficient) knowledge in the field of their company's activity, only six sampled companies replied that they do not possess enough knowledge, while 51 companies answered affirmatively to this question. Answers of participants to the question whether they are willing to attend trainings and seminars in order to complement the knowledge needed to improve the business operations are presented in Table 3.

Table 3: Willingness of participants to attend seminars

\begin{tabular}{|l|c|c|}
\hline \multicolumn{1}{|c|}{ Answer } & Number of companies & \% of participation \\
\hline Yes, regardless of the price & 14 & 24.56 \\
\hline Yes, if the price of the seminar is acceptable & 39 & 68.42 \\
\hline No & 4 & 7.02 \\
\hline \multicolumn{1}{c|}{ Total } & 57 & 100.00 \\
\hline
\end{tabular}

Source: Authors

By analyzing the answers to the question of whether the respondents attended organized trainings outside the seat of their company, we have noticed that most of them attended trainings organized by the Chambers of Commerce, international 
organizations and the Republic Agency for the Development of Small and Medium Enterprises. At the same time 34 participants who attended seminars or trainings were satisfied with the level of knowledge provided at the seminars, while 13 companies expressed their dissatisfaction with the knowledge provided at seminars. When it comes to the opinion of participants on whether enough relevant seminars and trainings for entrepreneurs are offered in their city, only 14 participants answered affirmatively, while 40 participants believed that there were not enough seminars and trainings in this field. Three participants did not give an answer to this question.

To the question "Do you consider that during your formal education you have acquired adequate knowledge needed to run a business?", there was an equal number of participants who believed that in the course of their formal education they acquired adequate knowledge needed to run a business, and those who thought the opposite (with $42 \%$ of answers of participants). On the other hand, $16 \%$ of participants answered they did not know whether they acquired adequate knowledge during formal education. When asked if they have a need for some current trainings or necessary skills in the business activity of owners/managers or staff, 24 companies believed that there was no need neither for owners nor for the staff, while 33 participants stated that there was a need either for the owner or for the staff. Based on the above mentioned questions related to the education of managers/owners, it was found that in our sample only about $23 \%$ of companies had managers with relevant experience and knowledge needed to run a business.

\section{Testing Hypotheses}

In this paper, we advanced one main and three auxiliary hypotheses. Confirmation or rejection of auxiliary hypotheses will lead to approval or rejection of the main hypothesis of this paper, which reads as follows:

H0: Application of entrepreneurial orientation in the sector of small and medium enterprises in small transition countries will contribute to achieving better performances in these companies.

The first, second and third auxiliary hypotheses will be argued below based on the statistical analysis of data collected from the research questionnaire. Based on the grouping of responses, we identified companies which have an expressed dimension of risk-taking, proactiveness and innovativeness and those which do not have it. Later, we observed data obtained in that way through the prism of selected indicators of business performances. The presence of entrepreneurial orientation from the standpoint of innovativeness, proactiveness and risk-taking, was measured by using a questionnaire that was tailored to our needs, and developed by the authors Covin and 
Slevin (1989). As for the indicators of business performances, we used a large number of indicators, which were calculated on the basis of financial reports from the APIF's database for the period 2012-2014. In that way we observed business success from different angles, i.e. from the point of liquidity, indebtedness, efficiency and yield, so in the analysis we used seven indicators of business performances: quick ratio, debt to equity ratio, customer turnover ratio, inventories and suppliers' turnover ratio, rate of return on assets, rate of return on sales and rate of return on equity. In the second and third hypothesis we took into consideration another indicator, and that was the growth of operating income in the observed three-year period from 2012 to 2014 , through which we analyzed sales growth and strengthening or weakening of the competitive position of the company.

The First Auxiliary Hypothesis (H1)

H1: The tendency of managers of SMEs to actively take risks will contribute to a better business success of the company.

In order to determine how much companies are prone to risk-taking, we requested from participants to mark the following statements with marks one (1) to five (5):

1. Your company prefers high-risk projects where the expected return is higher than the average of the branch.

2. According to report Doing Business 2017, BiH has an unfavorable business environment in comparison to the region. Regardless of the nature of the business environment in $\mathrm{BiH}$, you believe that your company still needs to take bold actions in order to achieve the company's goals.

3. When making decisions under uncertainty, your company usually takes an aggressive stance (it reacts without waiting for actions of competitors) in order to maximize the possibility to take advantage of potential opportunities.

In order to test this hypothesis, we observed the business success of participants from different angles, i.e. from the point of liquidity, indebtedness, efficiency and yield. In addition, we observed each of these indicators by several criteria in three years (2012, 2013 and 2014), so that in the following analysis we would have important arguments for the conclusion. Quick ratio is criterion by which companies which has a dimension of risk-taking do not differ statistically significantly from companies which do not have that dimension. We did not make this conclusion by applying the $t$ test, because there were no reasonable grounds for applying the same ${ }^{1}$. In the analysis we used its alternative - Mann-Whitney U test. Before this statistical test, the basic descriptive measures describing the value of this criterion by groups are given in Table 4. 
Table 4: Risk-taking in relation to quick ratio

\begin{tabular}{|c|l|r|r|r|c|}
\hline & Risk-taking & $\mathrm{N}$ & \multicolumn{1}{c|}{ mean } & Std. Deviation & Std. Error Mean \\
\hline \multirow{2}{*}{ Vr_2012 } & Have EO dimension & 17 & 1.4506 & 1.26653 & .30718 \\
\cline { 2 - 6 } & Do not have EO dimension & 39 & 1.4438 & 1.64318 & .26312 \\
\hline \multirow{2}{*}{ Vr_2013 } & Have EO dimension & 17 & 1.7765 & 1.63312 & .39609 \\
\cline { 2 - 6 } & Do not have EO dimension & 39 & 1.4233 & 2.28093 & .36524 \\
\hline Vr_2014 & Have EO dimension & 17 & 1.4024 & 1.13216 & .27459 \\
\hline & Do not have EO dimension & 39 & 1.6418 & 2.05261 & .32868 \\
\hline
\end{tabular}

Source: Authors' calculations in SPSS software

Results of Mann-Whitney U test of quick ratio are presented in Table 5 and it is evident that there is no statistically significant difference between companies that are entrepreneurially-oriented and companies that do not have the characteristics of EO.

Table 5: Mann-Whitney U test (quick ratio)

\begin{tabular}{|l|r|r|r|}
\hline & Vr_2012 & Vr_2013 & Vr_2014 \\
\hline Mann-Whitney U & 282,500 & 248,500 & 310,000 \\
\hline Wilcoxon W & 1062,500 & 1028,500 & 1090,000 \\
\hline Z & -.873 & -1.479 & -.383 \\
\hline Asymp. Sig. (2-tailed) & .383 & .139 & .702 \\
\hline
\end{tabular}

Source: Authors' calculations in SPSS software

Debt to equity ratio, as one of the criteria of indebtedness, is also characterized by a large deviation, i.e. the high standard deviation (Table 6), so instead of the classic $t$ test, we used its alternative from non-parametric tests (Mann-Whitney U test).

Table 6: Risk-taking in relation to debt to equity ratio

\begin{tabular}{|c|l|r|r|r|c|}
\hline & \multicolumn{1}{|c|}{ Risk-taking } & N & \multicolumn{1}{c|}{ Mean } & Std. Deviation & Std. Error Mean \\
\hline \multirow{2}{*}{ Vr_2012 } & Have EO dimension & 17 & 3.4612 & 8.70883 & 2.11220 \\
\cline { 2 - 6 } & Do not have EO dimension & 38 & 9.9268 & 32.72284 & 5.30835 \\
\hline \multirow{2}{*}{ Vr_2013 } & Have EO dimension & 17 & 7.0624 & 23.96780 & 5.81305 \\
\cline { 2 - 6 } & Do not have EO dimension & 38 & 5.2700 & 16.71198 & 2.71104 \\
\hline Vr_2014 & Have EO dimension & 17 & 8.7453 & 24.31953 & 5.89835 \\
\hline & Do not have EO dimension & 39 & 5.4138 & 16.30290 & 2.61055 \\
\hline
\end{tabular}

Source: Authors' calculations in SPSS software

In any case, the difference is not sufficiently pronounced to be considered statistically significant. In particular, these two groups of companies do not differ by this criterion as well, which is presented in Table 7. 
Table 7: Mann-Whitney U test statistics (debt to equity ratio)

\begin{tabular}{|l|c|c|c|}
\hline & Vr_2012 & Vr_2013 & Vr_2014 \\
\hline Mann-Whitney U & 320,000 & 322,000 & 279,000 \\
\hline Wilcoxon W & 473,000 & 475,000 & 1059,000 \\
\hline Z & -.055 & -.018 & -.936 \\
\hline Asymp. Sig. (2-tailed) & .956 & .985 & .349 \\
\hline
\end{tabular}

Source: Authors' calculations in SPSS software

Customer turnover ratio is the criterion where the average value in each year is almost doubled in companies that do not have the dimension of risk-taking than in those who have it (Table 8). However, these differences are not statistically significant, as evidenced by the above non-parametric test (Table 9).

Table 8: Risk-taking in relation to customer turnover ratio

\begin{tabular}{|c|l|c|c|r|r|}
\hline & \multicolumn{1}{|c|}{ Risk-taking } & $\mathrm{N}$ & \multicolumn{1}{c|}{ Mean } & Std. Deviation & \multicolumn{1}{c|}{ Std. Error Mean } \\
\hline \multirow{2}{*}{ Vr_2012 } & Have EO dimension & 16 & 4.3475 & 3.09379 & .77345 \\
\cline { 2 - 6 } & Do not have EO dimension & 39 & 8.2156 & 11.73401 & 1.87894 \\
\hline \multirow{2}{*}{ Vr_2013 } & Have EO dimension & 16 & 4.3281 & 2.38787 & .59697 \\
\cline { 2 - 6 } & Do not have EO dimension & 39 & 7.4523 & 8.87376 & 1.42094 \\
\hline Vr_2014 & Have EO dimension & 17 & 4.3188 & 2.51354 & .60962 \\
\hline & Do not have EO dimension & 39 & 7.0218 & 8.21231 & 1.31502 \\
\hline
\end{tabular}

Source: Authors' calculations in SPSS software

Table 9: Mann-Whitney U test statistics(customer turnover ratio)

\begin{tabular}{|l|c|c|c|}
\hline & Vr_2012 & Vr_2013 & Vr_2014 \\
\hline Mann-Whitney U & 248,500 & 273,500 & 281,500 \\
\hline Wilcoxon W & 384,500 & 409,500 & 434,500 \\
\hline Z & -1.177 & -.713 & -.891 \\
\hline Asymp. Sig. (2-tailed) & .239 & .476 & .373 \\
\hline
\end{tabular}

Source: Authors' calculations in SPSS software

Since we come to an identical conclusion by applying other criteria of efficiency (inventories and suppliers' turnover ratio), it can be said that these two groups do not differ statistically significantly when it comes to their efficiency. Finally, this hypothesis is tested by the criterion of yield. The rate of return of assets does not differ statistically significantly in 2012 and 2013, but in 2014 the difference was statistically significant and expressed. The same situation is with the rate of return on sales (only in 2014 the difference was statistically significant), while with the rate of return of equity the difference in all observed years was not statistically significant. 
Table 10: Mann-Whitney $\mathrm{U}$ test statistics (rate of return of assets)

\begin{tabular}{|l|r|r|r|}
\hline & Vr_2012 & Vr_2013 & Vr_2014 \\
\hline Mann-Whitney U & 294,000 & 271,500 & 188,000 \\
\hline Wilcoxon W & 447,000 & 424,500 & 341,000 \\
\hline Z & -.668 & -1.069 & -2.557 \\
\hline Asymp. Sig. (2-tailed) & .504 & .285 & $\mathbf{. 0 1 1}$ \\
\hline
\end{tabular}

Source: Authors' calculations in SPSS software

Based on everything said above, we conclude that managers' support to risk-taking strategies does not contribute to better business performance of SMEs and we reject the first auxiliary hypothesis.

The Second Auxiliary Hypothesis (H2)

$\mathrm{H} 2$ : Investments in research and development as well as technological and non-technological innovations, and implementation of new practices, will allow SMEs to increase sales growth.

In our case, in order to determine how innovative companies are, we asked participants to mark the following statements from 1-5:

1. Managers in your company favor research and development, innovation and technological leadership, but not marketing of already proven products and services.

2. In the last 3 years your company has launched a new line of products/services on the market.

3. In the last 3 years your company has made a lot of dramatic changes in the products and services.

In order to know whether the innovativeness of companies, in our sample, can lead to the growth of sales, we used the previous criteria, which directly or indirectly determine the sale. For practical reasons (to avoid duplication of the same tables and indicators) only the most important conclusions from statistical analysis are given below. From the standpoint of quick ratio, it cannot be said that the difference was statistically significant, because the so-called quick ratio is not significantly different by the observed groups. It should also be noted that the difference was not significant in all the observed years. An identical situation is when instead of quick ratio we analyze current ratio. 
Table 11: Mann-Whitney U test statistics (quick ratio)

\begin{tabular}{|l|r|r|r|}
\hline & Vr_2012 & Vr_2013 & Vr_2014 \\
\hline Mann-Whitney U & 352,000 & 349,000 & 337,500 \\
\hline Wilcoxon W & 583,000 & 580,000 & 568,500 \\
\hline Z & -.262 & -.313 & -.508 \\
\hline Asymp. Sig. (2-tailed) & .793 & .754 & .612 \\
\hline
\end{tabular}

Source: Authors' calculations in SPSS software

Further, when we observe indebtedness through the debt to equity ratio, which indirectly may affect the sales, we come to the same conclusion - the difference between the groups is not statistically significant.

Table 12: Mann-Whitney U test statistics (debt to equity ratio)

\begin{tabular}{|l|c|c|c|}
\hline & Vr_2012 & Vr_2013 & Vr_2014 \\
\hline Mann-Whitney U & 306,500 & 272,500 & 312,000 \\
\hline Wilcoxon W & 496,500 & 462,500 & 522,000 \\
\hline Z & -.471 & -1087 & -.665 \\
\hline Asymp. Sig. (2-tailed) & .638 & .277 & .506 \\
\hline
\end{tabular}

Source: Authors' calculations in SPSS software

Company's efficiency ratio gives us the same conclusions. Namely, turnover ratios of customer, inventories and suppliers are not statistically significantly different between the two groups of companies by these groups in all observed years.

Table 13: Mann-Whitney U test statistics (customer turnover ratio)

\begin{tabular}{|l|c|c|c|}
\hline & Vr_2012 & Vr_2013 & Vr_2014 \\
\hline Mann-Whitney U & 311,500 & 284,000 & 278,000 \\
\hline Wilcoxon W & 906,500 & 879,000 & 908,000 \\
\hline Z & -.788 & -1.265 & -1.515 \\
\hline Asymp. Sig. (2-tailed) & .431 & .206 & .130 \\
\hline
\end{tabular}

Source: Authors' calculations in SPSS software

In the analysis of yields, which we observe through the rate of return on sales, we come to the same conclusion. More specifically, by applying the above mentioned test it can be concluded that this indicator does not differ significantly between these groups. 
Table 14: Mann-Whitney U test statistics(rate of return on sales)

\begin{tabular}{|l|c|c|c|}
\hline & Vr_2012 & Vr_2013 & Vr_2014 \\
\hline Mann-Whitney U & 312,500 & 341,500 & 342,000 \\
\hline Wilcoxon W & 543,500 & 572,500 & 573,000 \\
\hline Z & -.931 & -.440 & -.432 \\
\hline Asymp. Sig. (2-tailed) & .352 & .660 & .666 \\
\hline
\end{tabular}

Source: Authors' calculations in SPSS software

Finally, we observe two groups of companies by increase in operating income for three years (2012, 2013 and 2014), as the best indicator for this hypothesis. We come to the conclusion that this indicator also does not differ significantly between the groups, which is reason enough to reject the hypothesis.

Table 15: Mann-Whitney U test statistics (increase in operating income)

\begin{tabular}{|l|r|}
\hline & Increase in income \\
\hline Mann-Whitney U & 342,000 \\
\hline Wilcoxon W & 573,000 \\
\hline Z & -.432 \\
\hline Asymp. Sig. (2-tailed) & .666 \\
\hline
\end{tabular}

Source: Authors' calculations in SPSS software

So, it was shown in our sample that investments in research and development, production and market, and technological innovations, and implementation of new practices (as determinants of innovativeness, by which we have classified companies in two groups), does not allow SMEs to improve sales growth, and therefore we reject the second auxiliary hypothesis.

The Third Auxiliary Hypothesis (H3)

$\mathrm{H} 3$ : Ability of the SMEs management or entrepreneur to act proactively will provide a better competitive position of the company.

In our case, in order to determine how proactive companies are, we asked participants to mark the following statements from 1-5:

1. Your company is usually first to initiate actions to which competitors have to answer.

2. Your company is usually among the first to introduce new products/services, and it implements advanced and innovative production processes and practices.

3. Compared to the competition, your company usually takes aggressive competitive stance. 
From the standpoint of proactiveness, companies are classified into two groups those which have a pronounced dimension of proactiveness in their work and those which do not have it. Of the total number of companies in our sample, for 26 of them it can be said that they are pro-active. Looking at the indicators of liquidity, indebtedness, efficiency and yield, we come to the conclusion that indicators do not differ by groups. In addition, it was found that the most important indicator for this hypothesis, which refers to the increase in operating income, does not differ by groups. As in previous analyses, the same indicators were identified, for comparability and consistency (which is presented in the tables 16-19), but it should be noted that we would also come to the same conclusion by applying other indicators. So, we reject the third auxiliary hypothesis as well.

Table 16: Mann-Whitney U test statistics (quick ratio)

\begin{tabular}{|l|c|c|c|}
\hline & Vr_2012 & Vr_2013 & Vr_2014 \\
\hline Mann-Whitney U & 337,000 & 314,000 & 286,500 \\
\hline Wilcoxon W & 688,000 & 665,000 & 637,500 \\
\hline Z & -.871 & -1.249 & -1.701 \\
\hline Asymp. Sig. (2-tailed) & .384 & .212 & 089 \\
\hline
\end{tabular}

Source: Authors' calculations in SPSS software

Table 17: Mann-Whitney U test statistics (customer turnover ratio)

\begin{tabular}{|l|c|c|c|}
\hline & Vr_2012 & Vr_2013 & Vr_2014 \\
\hline Mann-Whitney U & 374,500 & 309,000 & 313,000 \\
\hline Wilcoxon W & 809,500 & 744,000 & 778,000 \\
\hline Z & -.042 & -1.146 & -1.265 \\
\hline Asymp. Sig. (2-tailed) & .966 & .252 & .206 \\
\hline
\end{tabular}

Source: Authors' calculations in SPSS software

Table 18: Mann-Whitney U test statistics (rate of return on sales)

\begin{tabular}{|l|c|c|c|}
\hline & Vr_2012 & Vr_2013 & Vr_2014 \\
\hline Mann-Whitney U & 358,500 & 367,500 & 352,000 \\
\hline Wilcoxon W & 709,500 & 832,500 & 817,000 \\
\hline Z & -.518 & -.370 & -.624 \\
\hline Asymp. Sig. (2-tailed) & .605 & .712 & .532 \\
\hline
\end{tabular}

Source: Authors' calculations in SPSS software 
Table 19: Mann Whitney U test statistics (increase in operating income)

\begin{tabular}{|l|r|}
\hline & Increase in income \\
\hline Mann-Whitney U & 342,000 \\
\hline Wilcoxon W & 573,000 \\
\hline Z & -.432 \\
\hline Asymp. Sig. (2-tailed) & .666 \\
\hline
\end{tabular}

Source: Authors' calculations in SPSS software

Finally, for more accurate examination we conducted an observation of EO as a one-dimensional concept, i.e. we conducted a comparison of two groups of companies ( 7 companies that express all three dimensions and 50 companies that do not express it) and again it was done from the aspects of liquidity, indebtedness, efficiency and yield. It was found that these two groups of companies do not differ statistically significantly even when observed in this way, as can be seen from the tables 20-23.

Table 20: Mann-Whitney U test statistics (liquidity)

\begin{tabular}{|l|r|r|c|}
\hline & Vr_2012 & Vr_2013 & Vr_2014 \\
\hline Mann-Whitney U & 141,000 & 150,000 & 161,500 \\
\hline Wilcoxon W & $1,366,000$ & $1,375,000$ & $1,386,500$ \\
\hline Z & -.756 & -.533 & -.248 \\
\hline Asymp. Sig. (2-tailed) & .450 & .594 & .804 \\
\hline Exact Sig. [2* (1-tailed Sig.)] & $.466^{\mathrm{a}}$ & $.610^{\mathrm{a}}$ & $.808^{\mathrm{a}}$ \\
\hline
\end{tabular}

Source: Authors' calculations in SPSS software

Table 21: Mann-Whitney U test statistics (indebtedness)

\begin{tabular}{|l|r|r|r|}
\hline & Vr_2012 & Vr_2013 & \multicolumn{1}{|c|}{ Vr_2014 } \\
\hline Mann-Whitney U & 123,500 & 123,000 & 132,500 \\
\hline Wilcoxon W & 151,500 & 151,000 & 160,500 \\
\hline Z & -1.124 & -1.137 & -.966 \\
\hline Asymp. Sig. (2-tailed) & .261 & .256 & .334 \\
\hline Exact Sig. [2* (1-tailed Sig.)] & $.267^{\mathrm{a}}$ & $.267^{\mathrm{a}}$ & $.342^{\mathrm{a}}$ \\
\hline
\end{tabular}

Source: Authors' calculations in SPSS software 
Table 22: Mann-Whitney U test statistics (efficiency)

\begin{tabular}{|l|r|r|r|}
\hline & Vr_2012 & Vr_2013 & Vr_2014 \\
\hline Mann-Whitney U & 143,500 & 147,500 & 143,500 \\
\hline Wilcoxon W & $1,319,00$ & $1,323,500$ & $1,368,500$ \\
\hline Z & -.619 & -.518 & -.694 \\
\hline Asymp. Sig. (2-tailed) & .536 & .605 & .488 \\
\hline Exact Sig. [2* (1-tailed Sig.)] & $.544^{\mathrm{a}}$ & $.612^{\mathrm{a}}$ & $.496^{\mathrm{a}}$ \\
\hline
\end{tabular}

Source: Authors' calculations in SPSS software

Table 23: Mann Whitney U test statistics (yield)

\begin{tabular}{|l|r|r|r|}
\hline & Vr_2012 & Vr_2013 & Vr_2014 \\
\hline Mann-Whitney U & 138,000 & 138,500 & 134,000 \\
\hline Wilcoxon W & 166,000 & 166,500 & 162,000 \\
\hline Z & -.830 & -.818 & -.929 \\
\hline Asymp. Sig. (2-tailed) & .407 & .414 & .353 \\
\hline Exact Sig. [2 * (1-tailed Sig.)] & $.422^{\mathrm{a}}$ & $.422^{\mathrm{a}}$ & $.367^{\mathrm{a}}$ \\
\hline
\end{tabular}

Source: Authors' calculations in SPSS software

Based on the above presented statistical analysis, we did not find statistically significant deviations between the two groups of companies and we can conclude that the application of $\mathrm{EO}$ on a sample of SMEs from $\mathrm{BiH}$ does not contribute to achieving better business performances compared to companies that do not apply the concept of EO. Based on the above, our empirical research in $\mathrm{BiH}$ did not confirm the main research hypothesis which reads: Application of entrepreneurial orientation in the sector of small and medium enterprises in small transition countries will contribute to achieving better performances in these companies.

\section{Discussion}

Guided by the results of research and testing the auxiliary hypotheses, we concluded that the application of $\mathrm{EO}$ in companies in $\mathrm{BiH}$ in our sample did not have any influence on business performances in terms of achieving better business results compared to companies that were not entrepreneurially oriented. In the remainder of this paper we will compare obtained research results with the results of similar researches in the world, given that we did not find papers that dealt with this issue in our environment, with the exception of two papers that were published in Croatia and one research done in $\mathrm{BiH}$. Palalić and Bušatlić (2015) analyzed the environment in which operated fast-growing enterprises (gazelles) and slow growing enterprises 
(mice) by measuring the dimensions of EO and performance (growth in sales and number of employees) $178 \mathrm{SMEs}$ in $\mathrm{BiH}$. Their results showed a small to moderate significant correlation between the dimensions of $\mathrm{EO}$ and business gazelles and mice.

Morić Milovanović (2012) examined the impact of entrepreneurial orientation on financial and non-financial business performances of the Croatian manufacturing SMEs, then the impact of the environment on entrepreneurial orientation, as well as the moderating influence of the environment on the relationship between EO and business performances. Results of this research have shown that EO observed as a one-dimensional concept has a positive influence on the performances of Croatian manufacturing SMEs. In addition, they have shown that only the dimension of innovativeness expresses a significant influence on the business performance of these companies, while, when it comes to the dimension of risk-taking they have even found a negative impact. The positive influence of the environment on EO was not confirmed, except for the dimension of rivalry in the environment, nor was confirmed that the environment had a moderating influence on the relationship between EO and business performance. Tonković Grabovac and Morić Milovanović (2015) examined whether the setting of the five factor model of EO of Lumpkin and Dess could be applied to a sample of Croatian companies. Research results have confirmed that the five dimensions are important components of $\mathrm{EO}$ of Croatian entrepreneurs. In addition, research has shown that Croatian entrepreneurs are moderately entrepreneurially oriented, and that their most prominent component is proactiveness, and the least prominent component is tendency to risk. As stated in the theoretical part of the paper, there is no agreement in the literature over whether EO should be viewed as a one-dimensional or multi-dimensional strategic orientation. Thus, supporters of a one-dimensional approach consider it necessary for the company to be characterized by a high level in all dimensions in order to be considered entrepreneurial (Miller, 1983; Covin \& Slevin, 1989; Brown, Davidsson, \& Wiklund, 2001; Lee, Lee, \& Pennings, 2001, Wiklund, 1999 stated in Arbaugh, Cox \& Camp, 2009; Naman \& Slevin, 1993; Wiklund \& Shepherd, 2003). On the other hand, supporters of multi-dimensional approach assume that each of the dimensions gives a unique contribution to the overall level of EO, so if the organization has only one of them it can be considered entrepreneurial (Lumpkin \& Dess, 1996; Kreiser, Marino, \& Weaver, 2002; Lumpkin \& Dess, 2001, stated in Taylor, 2013; Hughes \& Morgan, 2007).

In our sample, only 7 of 57 observed companies or $12.28 \%$ of companies in the research sample show high levels of all three dimensions of EO. Observed individually by dimensions, it can be observed that proactiveness is the most pronounced dimension of EO (26 companies or 45.61\%), and risk-taking is the least pronounced (17 companies or $29.82 \%$ ). This result may be influenced by the fact that companies in $\mathrm{BiH}$ operate in a very unfavorable environment, which is characterized by specific political and economic conditions and instability, dominance of companies engaged in wholesale and retail trade, insufficiently developed legislation, complicated public 
tenders, unfair competition, etc. In addition, companies in $\mathrm{BiH}$ have low or no credit ratings, whereas they have high dependence on loans as the main external source of financing. The greatest part of their business activities is carried out in the local market. All these facts have most likely influenced the fact that we have in the sample a small percentage of companies (12.28\%) with a strongly pronounced EO. It should be noted that certain researches of EO have shown that EO is heavily influenced by the culture of a nation, and that there are differences in its appearance in different cultures. Both Lee and Peterson (2000) believe that only countries with specific cultural characteristics encourage a strong tendency towards innovativeness, proactiveness and risk-taking, and that economic, political and social factors can have a significant influence on this relationship.

Using the first three auxiliary hypotheses, whose purpose was to prove our main hypothesis, we tried to examine the influence of each individual dimension on business results of companies in the sample. None of the three hypotheses relating to the examination of the influence of $\mathrm{EO}$ on business performances has not been confirmed. Also, significant influence of EO on any of the selected indicators has not been confirmed. These results are somewhat in line with the results of the research presented in the theoretical part, since we stated that a number of authors found no significant relationship (Zahra, 1991; Dimitratos et al., 2004) or found no relationship at all between EO and business performances (Slater \& Narver, 2000; George et al., 2001). At the same time, most of the researches on this topic have been conducted in the USA (Rauch et al. 2009), while $\mathrm{BiH}$, as described above, represents a specific environment and as such is certainly significantly different from the American. However, when interpreting the results of the survey several things should be taken into account. One of the problems of the research on EO refers to the way of measuring this construct. This means that in the interpretation of the obtained results, one should keep in mind that EO was examined and evaluated based on the view of one person, that is based on a manager's or an entrepreneur's perception about tendencies of companies towards certain dimensions of EO, and this view does not have to match the actual EO of the company. What should also be taken into consideration is the fact that in the preparation of financial reports a great number of companies try to show their business results in a way to pay less taxes and contributions, so it is possible that performance indicators that we have used in the analysis do not reflect the real business performance of the company. Consequently, these results should be taken with some reserve. It is important to note that it is not possible to generalize the results of this research, taking into account the biggest limitation of this research, and that is the size of the sample. 


\section{Implications for Theory and Practice}

Our results found no relationship between EO and performances of SMEs in BiH. However, if we take into account the limitations that we encountered in this research and, as pointed out in the discussion the state of the environment in which companies operate and how they cope in the same environment, we should not conclude that companies in $\mathrm{BiH}$ as a small transition country should not apply EO. Therefore, business owners or managers are recommended to consider the application of the concept of EO in their organizations in some of the following ways:

$>$ through increased cooperation with universities and scientific research institutions, greater interest in recent researches carried out in the field of entrepreneurship and possible involvement of experts in this field, which would help companies to find the model that will best suit their organization, taking into account a number of factors that can influence the relation $\mathrm{EO}$ - performances,

$>$ sending its experts to trainings from entrepreneurship, organized by universities, institutes, agencies, Chamber of Commerce, etc.

$>$ continuous monitoring of the state of company's performances, in order to see how the introduction of one or more dimensions of EO reflects on different aspects of the business, etc.

On the other hand, the state must create conditions for a favorable environment. The above measures would allow companies to be more interested to direct their resources in the research and development of new or improvement of existing systems, processes, products and services. On the basis of the questionnaire, we found out that there was not enough training in the field of entrepreneurship. Yet, we should keep in mind that talents or "resourcefulness" are much more prominent in small enterprises, which were most represented in the questionnaire, somewhat less in medium-sized enterprises in which more attention should be paid to the distribution of responsibilities and powers, mode of organizing and managing the company. However, regardless of the above, the fact is that is necessary to increase the level of knowledge of owners and managers of SMEs in $\mathrm{BiH}$ in the field of entrepreneurship, in order to follow the latest findings in the world, which would then be implemented in their businesses, all through the organization of various trainings, workshops, seminars, symposia and conferences. Through this empirical research, we have given contribution to the development of theoretical concepts in the field of entrepreneurship and analysis of the possibilities of and limitations to the implementation of the concept of EO in conditions of transition of small emerging economy into a developed modern market economy. 


\section{Conclusions}

SMEs are one of the main drivers of economic development and prosperity of the developed countries, because of their ability to create new products, generate new jobs, as well as other benefits they have in comparison to large enterprises. Also, studies have shown that the EO is one of the ways to improve the business success of SMEs. The adoption of EO, as one of the basic strategic orientations of companies, was precisely the result of significance which entrepreneurial activities had on SMEs. The concept of EO gained great attention of researchers and became a central concept in the field of entrepreneurship, and the actuality of this concept is confirmed by a large number of researches that were in recent years focused on this topic. However, there is still no agreement on key issues such as what constitutes an EO and what its relationship with business performances is, and which factors can influence the nature of this relationship. When it comes to the benefits that the company could have by adopting EO, there are several scientifically proven and empirically confirmed benefits. Certainly the most important fact is that by adopting EO the company will improve its business performances. In addition, EO may have an influence on the company's ability to withstand difficulties in business. It can also be a potential source of competitive advantage, because it allows the company to timely recognize opportunities, as well as to create them by itself and thereby change the business environment, instead of just adapting to it. Given that there are conflicting opinions on whether the EO contributes to the improvement the business performances, empirical research that we conducted to test the set hypotheses was aimed at understanding the level of application of EO in SMEs in $\mathrm{BiH}$ and exploring the impact that it had on their performances. The results of the research have shown a lack of application of this concept in companies in $\mathrm{BiH}$. The main hypothesis, which says that the application of EO in the sector of SMEs contributes to achieving better performances in these companies, was not confirmed. However, it has already been said that from the results of this research we should not draw general conclusion that companies should not adopt the EO primarily, because of the basic limitation of this research and that is a small sample size, but also because of other limitations that we have previously mentioned.

We believe that the analysis of the results obtained in our research and comparison with the empirical results of other researches, enable the achievement of scientific and social objectives of this paper. This paper contributes to familiarizing the interested business owners with extremely current concept of EO and potential benefits that they can have from its adoption. Also, the paper contributes to the academic community in explaining the significance of the concept of EO, and creates a starting point for further researches in this field that are certainly needed for its fuller understanding, as well as greater recognition in our region.When we talk about directions and possibilities for further researches in this field, once again we need to 
address the biggest drawback, i.e. limitation of this research and that is the sample size. Future researches should be conducted on a much larger sample, because only in this way they contribute to more comprehensive and better understanding of the research issues. In this paper, EO was measured on the basis of perception of company's management. As it was stated in the theoretical part above, there are other methods for its measuring, either through the entrepreneurial behavior of companies or on the basis of historical data, so in future researches we should consider the use of additional means or instruments for measuring the construct of EO. A large number of authors state that the relationship between the EO and performances is affected by many other factors such as organizational structure, strategy and management, therefore we can recommend that in future researches the above mentioned relationship is examined in different contexts. This would mean that the analysis of the relationship between EO and company's performances should also involve moderators such as, for example, company's activity or company's size. This means that instead of measuring the direct influence of certain determinants on EO, it would be useful to examine their moderating effect in the relationship EO - business performances.

\section{ENDNOTES}

${ }^{1}$ A large deviation from the average, which does not make the arithmetic mean a representative measure (Authors' note.)

\section{REFERENCES}

Ács, Z.J., \& Naudé, W.A. (2013). Entrepreneurship, Stages of Development and Industrialization, In Szirmai, A., Naudé W.A. \& Alcorta L. (Eds). Pathways to Industrialization in the 21st Century. Oxford: Oxford University Press.

Ambad, S. N. A., \& Wahab, K. A. (2013). Entrepreneurial Orientation among Large Firms in Malaysia: Contingent Effects of Hostile Environments. International Journal of Business and Social Science, 4(16), 96-107.

Anderson, B.S., Kreiser, P.M., Kuratko, D.F., Hornsby, J.S., \& Eshima, J. (2015). Reconceptualizing entrepreneurial orientation. Strategic Management Journal, 36(10), 1579-1596. DOI:10.1002/ smj.2298.

Arbaugh, J. B., Cox L.A.W., \& Camp, S. M. (2009). Is Entrepreneurial Orientation a Global Construct? A Multi-Country Study of Entrepreneurial Orientation, Growth Strategy, and Performance. The Journal of Business Inquiry, 2009, 8(1), 12-25.

Audretsch, D.B., Ketlbach, M.C., \& Lehmann, E.E. (2006). Entrepreneurship and Economic Growth. Oxford: Oxford University Press.

Audretsch, D., \& Thurik, A. (2000). Capitalism and Democracy in the 21st Century: From the Managed to the Entrepreneurial Economy. Journal of Evolutionary Economics, 10(1), 17-34. DOI:10.1007/s001910050003. 
Brown, T. E., Davidsson, P., \& Wiklund, J. (2001). An Operationalization of Stevenson's Conceptualization of Entrepreneurship as Opportunity-based Firm Behavior. Strategic Management Journal, 22, 953-968. DOI:10.1002/smj.190.

Covin, J.G., \& Miller, D. (2014). International entrepreneurial orientation: Conceptual considerations, research themes, measurement issues, and future research directions. Entrepreneurship: Theory \& Practice, 38(1), 11-44. DOI:10.1111/etap.12027.

Covin, J.G., \& Wales, W.J. (2012). The measurement of entrepreneurial orientation. Entrepreneurship: Theory \& Practice, 36(4), 677-702. DOI: 10.1111/j.1540-6520.2010.00432.x.

Covin, J.G., \& Lumpkin, G.T. (2011). Entrepreneurial orientation theory and research: Reflections on a needed construct. Entrepreneurship: Theory \& Practice, 35(5), 855-872. DOI: 10.1111/j.1540-6520.2011.00482.x.

Covin, J. G., Green, K., \& Slevin, D. P. (2006). Strategic Process Effects on the Entrepreneurial Orientation - Sales Growth Rate Relationship. Entrepreneurship Theory and Practice, 30(1), 57-81. DOI: $10.1111 / \mathrm{j} .1540-6520.2006 .00110 . x$.

Covin, J. G., \& Slevin, D. P. (1991). A conceptual model of entrepreneurship as firm behavior. Entrepreneurship: Theory and Practice, 16(1), 7-24.

Covin, J.G., \& Slevin, D.P. (1989). Strategic management of small firms in hostile and benign environments. Strategic Management Journal, 10, 75-87. DOI: 10.1002/smj.4250100107.

Covin, J.G., \& Slevin, D. P. (1986), The development and testing of an organizational-level entrepreneurship scale. In R. Ronstadt, J. A., Hornaday, R. P., \& Vesper, K. H. (Eds), Frontiers of Entrepreneurship Research 1986 (pp. 628-639). Wellesley, MA: Center for Entrepreneurial Studies, Babson College.

Coulthard, M. (2007). The Role of Entrepreneurial Orientation on Firm Performance and the Potential Influence of Relational Dynamism. Journal of Global Business and Technology, 3(1), 29-39.

Dimitratos, P., Lioukas, S., \& Carter, S. (2004). The relationship between entrepreneurship and International Performance: The importance of domestic environment. International Business Review, 13(1), 19-41. DOI: 10.1016/j.ibusrev.2003.08.001.

Edmond, V., \& Wiklund, J. (2010). The historic roots of Entrepreneurial Orientation research. In Landström, H., \& Lohrke, F. (Eds.), Historical Foundations of Entrepreneurship Research, pp.142-160. Northampton, MA: Edward Elgar Publishing.

European Commission. (2013). Commission Staff Working Document, Bosnia and Herzegovina 2013 Progress Report, Accompanying the document Communication from the Commission to the European Parliament and the Council), Retrieved September 23, 2016, from http://komorabih.ba/wp-content/uploads/2013/11/izvjestaj_napredak.pdf.

European Commission. (2008). Think Small First. A Small Business Act for Europe. \{SEC(2008) 2101\},\{SEC(2008) 2102\}, Retrived July 18, 2014, from http://ec.europa.eu/enterprise/policies/ sme/files/docs/sba/sba_ia_en.pdf $>$.

George, G., Wood, D.R., \& Khan, R. (2001). Networking Strategy of Boards: Implications for Small and Medium-Sized Enterprises. Entrepreneurship and Regional Development, 13(3), 269285. DOI: $10.1080 / 08985620110058115$.

Hisrich, R.D., Petković, S., Ramadani, V., \& Dana, L.P. (2016). Venture Capital Funds in Transition Countries: Insights from Bosnia and Herzegovina and Macedonia. Journal of Small Business and Enterprise Development, 23(2), 296-315, DOI: 10.1108/JSBED-06-2015-0078.

Hughes, M., \& Morgan R.E. (2007). Deconstructing the relationship between entrepreneurial orientation and business performance at the embryonic stage of firm growth. Industrial Marketing Management, 36, 651-661. DOI: 10.1016/j.indmarman.2006.04.003.

Ittner, C. D., \& Larcker, D.F. (1998). Innovations in Performance Measurement: Trends and Research Implications. Journal of Management Accounting Research, 10, 205-238. 
Knight, G. (2000). Entrepreneurship and marketing strategy: the SME under globalization. Journal of International Marketing, 8(2), 12-32. DOI: 10.1509/jimk.8.2.12.19620.

Kreiser, P. M., Marino, L. D., \& Weaver, K. M. (2002). Assessing the psychometric properties of the entrepreneurial orientation scale: A multi-country analysis. Entrepreneurship Theory and Practice, 26(4), 71-95.

Kropp, F., \& Zolin, R. (2005). Technological entrepreneurship: the role of small business innovation research. Programs Academy of Marketing Science Review, 2005(7), 1-14. Retrieved December 5, 2012, from http://www.amsreview.org/ articles/kropp07-2005.pdf.

Lee, C., Lee, K., \& Pennings, J. M. (2001). Internal capabilities, external networks, and performance: a study on technology-based ventures. Strategic Management Journal, 22 (6-7), 615-640. DOI: $10.1002 / \mathrm{smj} .181$.

Lee, S. M., \& Peterson, S. J. (2000). Culture, Entrepreneurial Orientation and Global Competitiveness. Journal of World Business, 35(4), 401-416. DOI: 10.1016/S1090-9516(00)00045-6.

Li, C-Y. (2012). The influence of entrepreneurial orientation on technology commercialization: the moderating roles of technological turbulence and integration. African Journal of Business Management, 6(1), 370-387. DOI: 10.5897/AJBM11.025.

Lieberman, M., \& Montgomery, D. (1988). First-mover advantages. Strategic Management Journal, Special Issue 9, 41-58. DOI: 10.1002/smj.4250090706.

Lumpkin, G.T., \& Dess, G.G. (2001). Linking two dimensions of entrepreneurial orientation to firm performance: the moderating role of environment and industry life cycle. Journal of Business Venturing, 16(5), 429-451. DOI: 10.1016/S0883-9026(00)00048-3.

Lumpkin, G.T., \& Dess, G.G. (1996). Clarifying the Entrepreneurial Orientation Construct and Linking It to Performance. The Academy of Management Review, 21(1), 135-172.

Miller, D. (1983). The correlates of entrepreneurship in three types of firms. Management Science, 29 (7), 770-791. DOI: $10.1287 / \mathrm{mnsc} \cdot 29.7 .770$.

Morgan, R. E., \& Strong, C. A. (2003). Business performance and dimensions of strategic orientation. Journal of Business Research, 56(3), 163-176. DOI: 10.1016/S0148-2963(01)00218-1.

Morić Milovanović, B. (2012). Moderatorni utjecaj okoline na odnos između poduzetničke orijentacije i poslovne uspješnosti hrvatskih malih i srednjih proizvodnih poduzeća. Poslovna izvrsnost, 6(2), 9-23.

Naman, J. L., \& Slevin, D. P. (1993). Entrepreneurship and the concept of fit: A model and empirical tests. Strategic Management Journal, 14, 137-153. DOI: 10.1002/smj.4250140205.

Nasution, H.N., Mavondo, F.T., Matanda, M.J., \& Ndubisi, N.O. (2011). Entrepreneurship: Its relationship with market orientation and learning orientation and as antecedents to innovation and customer value. Industrial Marketing Management, 40(3), 336-345. DOI: 10.1016/j.indmarman.2010.08.002.

Naudé, W. (2013). Entrepreneurship and Economic Development: Theory, Evidence and Policy; IZA DPNo.7507. Retrieved October 31, 2016, from http:/ftp.iza.org/dp7507.pdf

Official Gazette of the Republic of Srpska. (2013). Law on SMEs Development. Official Gazette of the Republic of Srpska No. 50/13.

Patel, P.C., \& D'Souza, R. R. (2009). Leveraging Entrepreneurial Orientation to Enhance SME Export Performance, An Office of Advocacy Working Paper, (337). Retrieved October 13, 2016, from <https://www.sba.gov/sites/default/files/Leveraging\%20Entrepreneurial\%20Orientation\%20to\%20Enhance\%20SME\%20Export\%20Performance\%202.pdf>.

Palalić, R., \& Bušatlić, S. (2015). Exploratory Research on Relationship between Entrepreneurial Orientation Dimensions and Business Performance and Growth of Fast and Slow Growing Small and Medium Enterprises in Bosnia and Herzegovina. International Journal of Business and Management, 10(2), 15-30. DOI: 10.5539/ijbm.v10n2p15. 
Ramadani, V., \& Dana, L.P. (2013). The state of entrepreneurship in the Balkans: Evidence from selected countries, in Ramadani, V. and Schneider, R.C. (Eds.), Entrepreneurship in the Balkans, pp. 217-250. Heidelberg: Springer. DOI: 10.1007/978-3-642-36577-5_12.

Rauch, A., Wiklund, J., Frese, M., \& Lumpkin, G.T. (2009). Entrepreneurial orientation and business performance: An assessment of past research and suggestions for the future. Entrepreneurship Theory and Practice. 33(3), 761-787. DOI:10.1111/j.1540-6520.2009.00308.x.

Rauch, A., Wiklund, J., Freese, M., \& Lumpkin, G. T. (2004). Entrepreneurial orientation and business performance: Cumulative empirical evidence. Paper presented at the 23rd Babson College Entrepreneurship Research Conference.

Rezaei J., Ortt, R., \& Scholten, V. (2013). An improved fuzzy preference programming to evaluate entrepreneurship orientation. Applied Soft Computing, 13 (5), 2749-2758. DOI:10.1016/j. asoc.2012.11.012.

Schumpeter JA (1934). The theory of economic development. Harvard University Press: Cambridge, MA.

Schumpeter JA (1942). Capitalism, socialism, and democracy. Harper \& Brothers: New York.

Slater, N., and Narver, J.C. (2000). The positive effect of market orientation on business profitability: A balance Replication. Journal of Business Review, 48, 69-73. DOI:10.1016/S01482963(98)00077-0.

Soininen, S. (2013). Entrepreneurial orientation in small and medium-sized enterprises during economic crisis. Unpublished doctoral dissertation, Lappeenranta University of Technology, Lappeenranta, Finland.

Tangen, S. (2004). Evaluation and Revision of Performance Measurement Systems. Unpublished doctoral dissertation, Department of Production Engineering, The Royal Institute of Technology, Stockholm, Sweden.

Taylor, P. (2013). The effect of entrepreneurial orientation on the internationalization of SMEs in developing countries. African Journal of Business Management, 7(19), 1927-1937.

The World Bank. (2017). Doing Business 2017. Equal Opportunity for All. Economy profile 2017. Bosnia and Herzegovina. 14 ${ }^{\text {th }}$ Ed. Retrieved January 2017, from http://www.doingbusiness.org/ reports/global-reports/ /media/WBG/DoingBusiness/documents/profiles/country/BIH.pdf.

Tonković Grabovac, M. i Morić Milovanović, B. (2015), Provjera osnovnih postavki modela poduzetničke orijentacije na hrvatskim poduzetnicima, Suvremena psihologija 18 1, 21-41.

Trivić, J., \& Petković, S. (2015). Different Features of Transition Economies-Institutional Matter. In Dana, L.P. and Ramadani. V. (Eds.), Family Businesses in Transition Economies. Management, Succession and Internationalization (pp. 71-96). New York, Heidelberg, Dordrecht, London: Springer International Publishing. DOI 10.1007/978-3-319-14209-8_4.

Van Praag, C.M., \& Versloot, P.H. (2007). What is the value of entrepreneurship? A review of recent research. Small business economics, 29 (4), 351-382. DOI: 10.1007/s11187-007-9074-x.

Vij, S., \& Bedi, H. S. (2012). Relationship between Entrepreneurial Orientation and Business Performance: A Review of Literature. The IUP Journal of Business Strategy, 9 (3), 17-31.

Wales, W.J. (2016). Entrepreneurial orientation: A review and synthesis of promising research directions. International Small Business Journal, 34(1), 3-15. DOI: 10.1177/02662 42615613840.

Wang, H.-K., \& Yen, Y.-F. (2012). An empirical exploration of corporate entrepreneurial orientation and performance in Taiwanese SMEs: a perspective of multidimensional construct. Total Quality Management \& Business Excellence, 23(9), 1035-1044. DOI: 10.1080/14783363.2012.670917.

Wiklund, J., \& Shepherd, D. (2005). Entrepreneurial orientation and small business performance: A configuration approach. Journal of Business Venturing, 20(1), 71-91. DOI: 10.1016/j. jbusvent.2004.01.001. 
Wiklund, J., \& Shepherd, D. (2003). Knowledge-based resources, entrepreneurial orientation, and the performance of small and medium-sized businesses. Strategic Management Journal, 7(24), 1307-1314. DOI: $10.1002 / \mathrm{smj} .360$.

Wiklund, J. (1999). The sustainability of the entrepreneurial orientation-performance relationship. Entrepreneurship Theory and Practice, 24(1), 37-48.

Yoo, K. (2015). A Comparative Study of Cultural Dimension as an Influencing Factor to Entrepreneurial Orientation. International Journal of Business and Social Science, 6(2),192-206

Zahra, S. A., \& Covin, J. G. (1995). Contextual influences on the corporate entrepreneurship performance relationship: A longitudinal analysis. Journal of Business Venturing, 10(3), 43-58. DOI: 10.1016/0883-9026(94)00004-E.

Zahra, S.A. (1991). Predictors and financial outcomes of corporate entrepreneurship: An exploratory study. Journal of Business Venturing, 6(4), 259-285. DOI: 10.1016/0883-9026(91)90019-A. 